Barker, P.F., Camerlenghi, A., Acton, G.D., and Ramsay, A.T.S. (Eds.)

Proceedings of the Ocean Drilling Program, Scientific Results Volume 178

\title{
27. DATA REPORT: StRONTIUM ISOTOPE DATING OF BARNACLE FraGMENTS: Antarctic Peninsula Site 1103'
}

\author{
Mark Lavelle, ${ }^{2,3}$ Peter F. Barker, ${ }^{2}$ and Lisa E. Osterman ${ }^{4}$
}

\begin{abstract}
Strontium isotope ratios from multiple plates of two barnacle fragments from Site 1103 (Ocean Drilling Program Leg 178) provide maximum age estimates for the oldest glacial sedimentary package drilled. Three moderately preserved barnacle fragments from 262.63 meters below seafloor (mbsf) yielded a mean best-fit age of 7.4 Ma. A single, wellpreserved fragment from the same horizon yielded a best-fit age of 12.2 Ma. Two moderately preserved fragments from 262.98 mbsf yielded a mean best-fit age of 7.8 Ma. The calculated mean strontium ages of 7.8 and $7.4 \mathrm{Ma}$ agree well with the diatom estimates of 8.68 to $5.89 \mathrm{Ma}$ for the underlying sediments.

\section{INTRODUCTION}

Antarctic Peninsula Site 1103 (Ocean Drilling Program [ODP] Leg 178) was part of a transect drilled along a shallow progradational lobe of the continental shelf, off Anvers Island (Barker, Camerlenghi, Acton, et al., 1999). The recovered sedimentary facies record deposition of debris flows and poorly sorted turbidites on an active glacially influenced slope. Shipboard biostratigraphic analyses of the deepest drilled glacial sediments (Sequence Group S3) provided poor age assignments of prePliocene, possibly late Miocene age (Shipboard Scientific Party, 1999).

${ }^{1}$ Lavelle, M., Barker, P.F., and Osterman, L.E., 2001. Data report: Strontium isotope dating of barnacle fragments: Antarctic Peninsula Site 1103. In Barker, P.F., Camerlenghi, A., Acton, G.D., and Ramsay, A.T.S. (Eds.), Proc. ODP, Sci. Results, 178, 1-8 [Online]. Available from World Wide Web: <http://www-odp.tamu.edu/ publications/178_SR/VOLUME/ CHAPTERS/SR178_27.PDF>. [Cited YYYY-MM-DD]

${ }^{2}$ British Antarctic Survey, Madingley Road, Cambridge CB3 OET, United Kingdom. Correspondence author: m.lavelle@bas.ac.uk

${ }^{3}$ Department of Earth Sciences, University of Cambridge, Downing St., Cambridge CB2 3EQ, United Kingdom.

${ }^{4}$ U.S. Geological Survey, MS 926A, Reston VA 20192, USA.

Initial receipt: 14 August 2000 Acceptance: 6 September 2001 Web publication: 20 December 2001

Ms 178SR-211
\end{abstract}




\section{MATERIALS AND METHODS}

Two individual barnacle fragments, each composed of multiple plates, were recovered from a $>5$-m-thick well-consolidated massive muddy diamictite at 262.63 meters below seafloor (mbsf) (Sample 1781103A-28R-5, 93-95 cm) and 262.98 mbsf (Sample 178-1103A-28R-5, $127-129 \mathrm{~cm})(\mathrm{Pl} . \mathrm{P1})$. The recovered fragments are of the same unidentified species and were not attached to a hard substrate when recovered.

A review of the strontium isotope dating technique, including diagenetic considerations, is presented by Lavelle and Armstrong (1993) and McArthur (1994). In summary, surficial contaminants were removed from the fragmented shell surface by repeated 10-s ultrasound treatment in 1-M acetic acid and quartz-distilled water. All samples were visually inspected using a binocular microscope, and homogeneous and well-preserved macrofossil specimens were divided into working and archive splits. The archive fractions were examined using a scanning electron microscope (SEM) to identify original shell ultrastructure at the submicron scale (Pl. P2). For archive samples that were identified as homogenous and well preserved, the matching working halves were rinsed in distilled water in an ultrasonic tank and dissolved in quartzdistilled 1.75-M HCl.

Strontium was extracted using standard ion-exchange techniques and was loaded onto a tantalum filament as a nitrate. Isotope measurements were carried out using a VG Sector 54 mass spectrometer at the Department of Earth Sciences, University of Cambridge. ${ }^{87} \mathrm{Sr} /{ }^{86} \mathrm{Sr}$ ratios were normalized to our long-term laboratory value of NIST-987 = $0.7210249(N=107 ; 2 \sigma=0.000017)$. Measurements were also normalized to ${ }^{86} \mathrm{Sr} /{ }^{88} \mathrm{Sr}=0.1194$. Analytical blanks were typically $<100 \mathrm{pg} \mathrm{Sr}$. Corrected mean isotope measurements were converted to best-fit age and uncertainty using the LOWESS fit to the marine Sr curve of Howarth and McArthur (1997) (look-up table version 3: 10/99). As we have no long-term laboratory average ${ }^{87} \mathrm{Sr} /{ }^{86} \mathrm{Sr}$ value for modern biogenic carbonate, the long-term precision value for NIST-987 was used to calculate the $95 \%$ confidence limits on the best-fit age. No statistical attempt has been made to reduce sampling and analytical uncertainty below that of the long-term standard deviation value $\left(17 \times 10^{-6}\right)$. The $\mathrm{Sr}$ isotope ages are calibrated to the timescales of Shackleton et al. (1994) (0-7 Ma) and Cande and Kent (1995) (7-72 Ma).

\section{RESULTS AND DISCUSSION}

Interpreted SEM images of the six analyzed samples are presented in Plate P2. Strontium isotope results are summarized in Table T1 and plotted in Figure F1. Four barnacle fragments were analyzed from Sample 178-1103A-28R-5, 93-95 cm (262.63 mbsf). Samples 1-3 show homogeneous carbonate and the moderate preservation of sheet nacre (P1. P2, figs. 1-3), which produced a mean age of $7.4(+1.5 /-0.9)$ Ma. Sample 4 shows very well-preserved sheet nacre and produced a significantly older age of $12.2(+1.2 /-1.1)$ Ma. Two individual barnacle fragments were analyzed from Sample 178-1103A-28R-5, 127-129 cm (262.98 mbsf). Samples 5 and 6 reveal sheet nacre and homogeneous carbonate, respectively (Pl. P2, figs. 5,6$)$ and produced a mean age of $7.8(+1.5 /-1.1)$ Ma.
P1. Photograph of barnacle with intact shell, p. 7 .

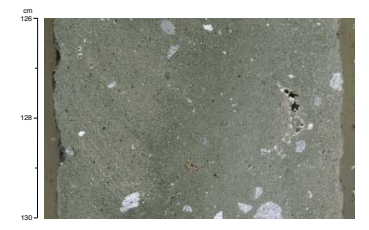

P2. SEM images of barnacle fragments, p. 8.

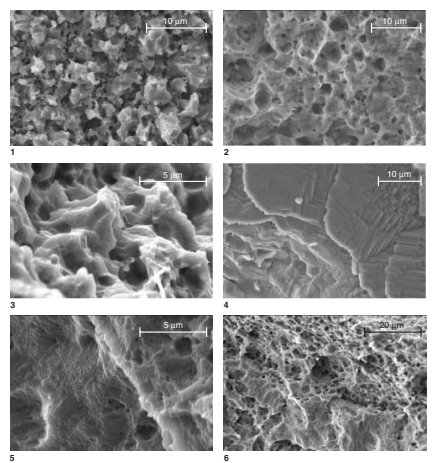

T1. Sr isotope data for barnacles, p. 6.

F1. Sr isotope vs. calculated age, p. 5 .

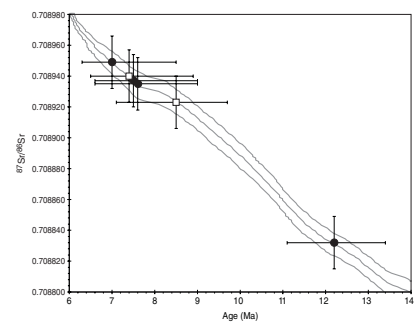


M. LAVELLE ET AL.

The SEM images reveal three preservational groups: homogeneous microcrystalline carbonate (Samples 1 and 6), moderately preserved sheet nacre (Samples 2, 3, and 5), and well-preserved sheet nacre (Sample 4). All SEM images were taken from an oblique vertical angle. Support for the 7.4- and 7.8-Ma best-fit ages are provided by independent biostratigraphic evidence. The underlying sediments between 320 and 355 mbsf are placed in the Actinocyclus ingens var. ovalis diatom zone (8.68-5.89 Ma) (M. Iwai, unpubl. data).

A cautious approach is taken in linking measured age to depositional age. Although the diamict is interpreted as a sediment gravity-flow deposit (Shipboard Scientific Party, 1999), the preservation of multiple articulated plates suggests that postdepositional transport of the barnacle fragments was minimal (see Plate P1). Bearing in mind the likely proximal proglacial environment, both specimens likely originate from the same biocoenosis. Even were this not so, the high sedimentation rates associated with proglacial Antarctic margin settings often result in minimally reworked ages that are within the uncertainty of the true depositional age (Lavelle, 2000). The most likely interpretation of our data is that Samples 1-3 and 5-6 represent approximate mean depositional ages of $\sim 7.4$ and $\sim 7.8 \mathrm{Ma}$ for sediments at 262.63 and $262.98 \mathrm{mbsf}$, respectively, and that Sample 4 ( $12.2 \mathrm{Ma})$ represents analytical error. Unless additional shell fragments are discovered in the lower half of Hole $1103 \mathrm{~A}$, no further specific conclusions may be drawn.

\section{ACKNOWLEDGMENTS}

This research used samples and/or data provided by the Ocean Drilling Program (ODP). ODP is sponsored by the U.S. National Science Foundation (NSF) and participating countries under management of Joint Oceanographic Institutions (JOI), Inc. Funding for these measurements was provided by the British Antarctic Survey. 


\section{REFERENCES}

Barker, P.F., Camerlenghi, A., Acton, G.D., et al., 1999. Proc. ODP, Init. Repts., 178 [Online]. Available from World Wide Web: <http://www-odp.tamu.edu/publications/178_IR/178TOC.HTM>. [Cited 2000-08-08].

Cande, S.C., and Kent, D.V., 1995. Revised calibration of the geomagnetic polarity timescale for the Late Cretaceous and Cenozoic. J. Geophys. Res., 100:6093-6095.

Howarth, R.J., and McArthur, J.M., 1997. Statistics for strontium isotope stratigraphy: a robust LOWESS fit to the marine Sr-isotope curve for 0 to $260 \mathrm{Ma}$, with look-up table for the derivation of numerical age. J. Geol., 105:441-456. [Look-up table version 3: 10/99.]

Lavelle, M., 2000. Strontium isotope stratigraphy and age model for the CRP-2/2A core, Ross Sea, Antarctica. Terra Antart., 7:611-620.

Lavelle, M., and Armstrong, R.A., 1993. Strontium isotope ratios in modern marine biogenic and chemical marine precipitates from southern Africa. S. Afr. J. Sci., 89:553-536.

McArthur, J.M., 1994. Recent trends in strontium isotope stratigraphy. Terra Nova, 6:331-358.

Shackleton, N.J., Crowhurst, S., Hagelberg, T., Pisias, N.G., and Schneider, D.A., 1994. A new late Neogene time scale: application to Leg 138 sites. In Pisias, N.G., Mayer, L.A., Janecek, T.R., Palmer-Julson, A., and van Andel, T.H. (Eds.), Proc. ODP, Sci. Results, 138: College Station, TX (Ocean Drilling Program), 73-101.

Shipboard Scientific Party, 1999. Shelf Transect (Sites 1100, 1102, and 1103). In Barker, P.F., Camerlenghi, A., Acton, G.D., et al., Proc. ODP, Init. Repts., 178 [Online]. Available from World Wide Web: <http://www-odp.tamu.edu/publications/178_IR/chap_09/chap_09.htm>. [Cited 2000-08-08]. 
M. LAVELLE ET AL.

DATA Report: Sr Isotope Dating of BARnACLE Fragments

Figure F1. Strontium isotope results vs. calculated age, Site 1103. Solid circles $=262.63 \mathrm{mbsf}$; open squares $=262.98$ mbsf. $\mathrm{X}$ - and $\mathrm{y}$-axis error bars represent combined timescale and analytical $2-\sigma$ errors. Gray lines represent the best-fit age and 95\% confidence limits of the LOWESS fit to the marine Sr isotope curve of Howarth and McArthur (1997).

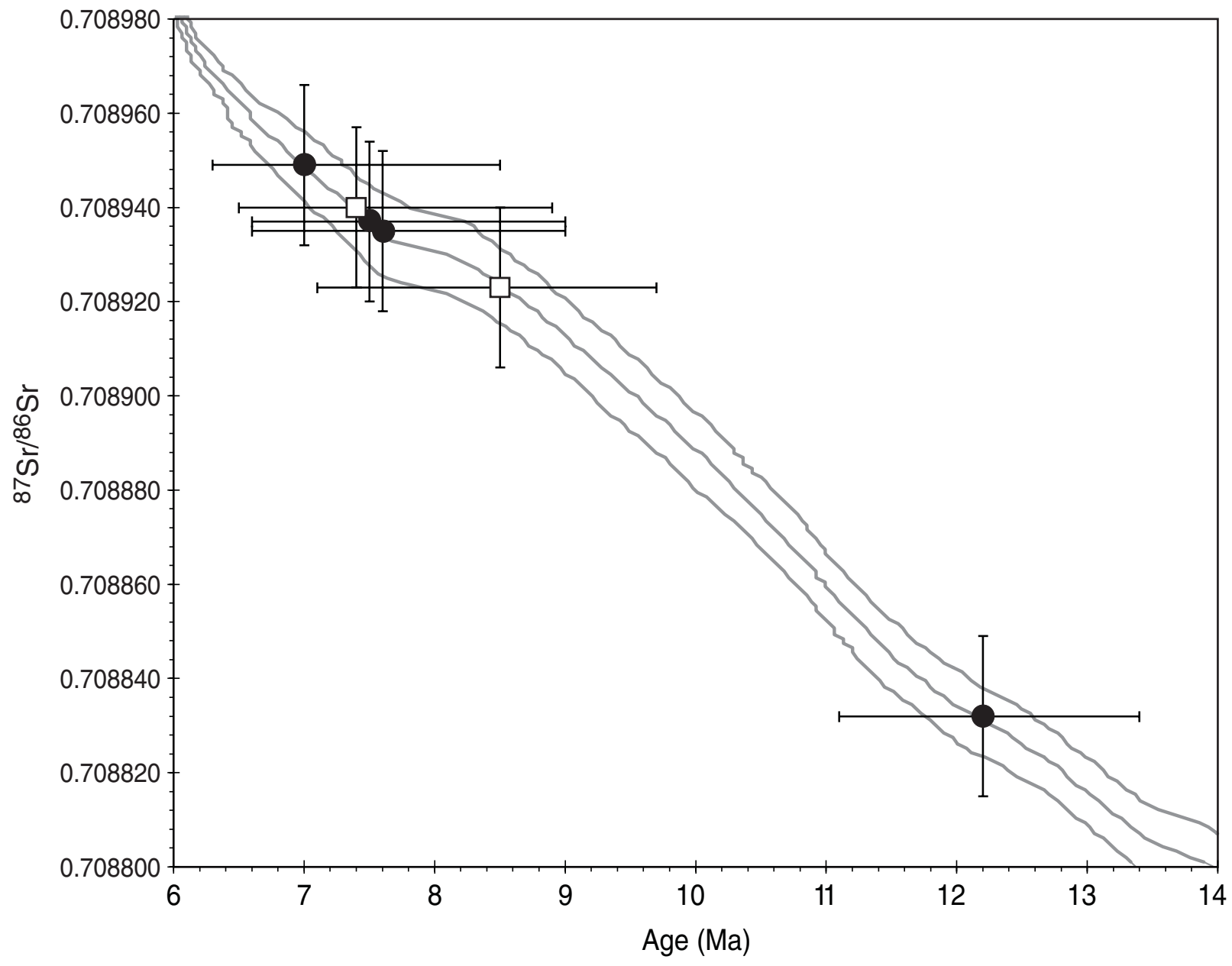


M. LAVELLE ET AL.

DATA Report: Sr Isotope DATINg of BARnACLE Fragments

Table T1. Strontium isotope data for marine barnacles, Site 1102.

\begin{tabular}{|c|c|c|c|c|c|c|c|c|c|}
\hline $\begin{array}{l}\text { Core, section, } \\
\text { interval }(\mathrm{cm})\end{array}$ & $\begin{array}{l}\text { Depth } \\
\text { (mbsf) }\end{array}$ & Sample & Shell type & Preservation & ${ }^{87} \mathrm{Sr} /{ }^{86} \mathrm{Sr}$ & $\begin{array}{l}\text { Uncertainty } \\
\text { 2SE }\left(\times 10^{-6}\right)\end{array}$ & $\begin{array}{c}\text { Age (Ma) } \\
\text { (Best fit) }\end{array}$ & $\begin{array}{l}\text { Age (Ma) } \\
\text { (UCL) }\end{array}$ & $\begin{array}{l}\text { Age (Ma) } \\
\text { (LCL) }\end{array}$ \\
\hline \multicolumn{10}{|l|}{ 178-1103A- } \\
\hline 1 & 262.63 & Barnacle (unidentified) & Fragment & Moderate & 0.708950 & 13 & 7 & 8.5 & 6.3 \\
\hline 2 & 262.63 & Barnacle (unidentified) & Fragment & Moderate & 0.708938 & 15 & 7.5 & 9 & 6.6 \\
\hline \multirow[t]{2}{*}{3} & 262.63 & Barnacle (unidentified) & Fragment & Moderate & 0.708936 & 13 & 7.6 & 9.1 & 6.6 \\
\hline & & & & Mean & 0.708941 & 17 & 7.4 & 8.9 & 6.5 \\
\hline 4 & 262.63 & Barnacle (unidentified) & Fragment & Excellent & 0.708833 & 14 & 12.2 & 13.4 & 11.1 \\
\hline \multicolumn{10}{|l|}{$28 \mathrm{R}-5,128-130$} \\
\hline 5 & 262.98 & Barnacle (unidentified) & Fragment & Moderate & 0.708941 & 14 & 7.4 & 8.9 & 6.5 \\
\hline \multirow[t]{2}{*}{6} & 262.98 & Barnacle (unidentified) & Fragment & Moderate & 0.708924 & 17 & 8.5 & 9.7 & 7.1 \\
\hline & & & & Mean & 0.708933 & 17 & 7.8 & 9.3 & 6.7 \\
\hline
\end{tabular}

Notes: $\mathrm{UCL}=$ upper confidence limit, $\mathrm{LCL}=$ lower confidence limit. Reference numbers refer to Plate P2, p. 8. 
M. LAVELLE ET AL.

DATA REPort: Sr ISOTOPE DATING OF BARnACLE Fragments

Plate P1. Shipboard photograph of the barnacle at 262.98 mbsf within the archive half of Section 1781103A-28R-5. The intact, crescent-shaped shell is clearly visible.

$\mathrm{cm}$

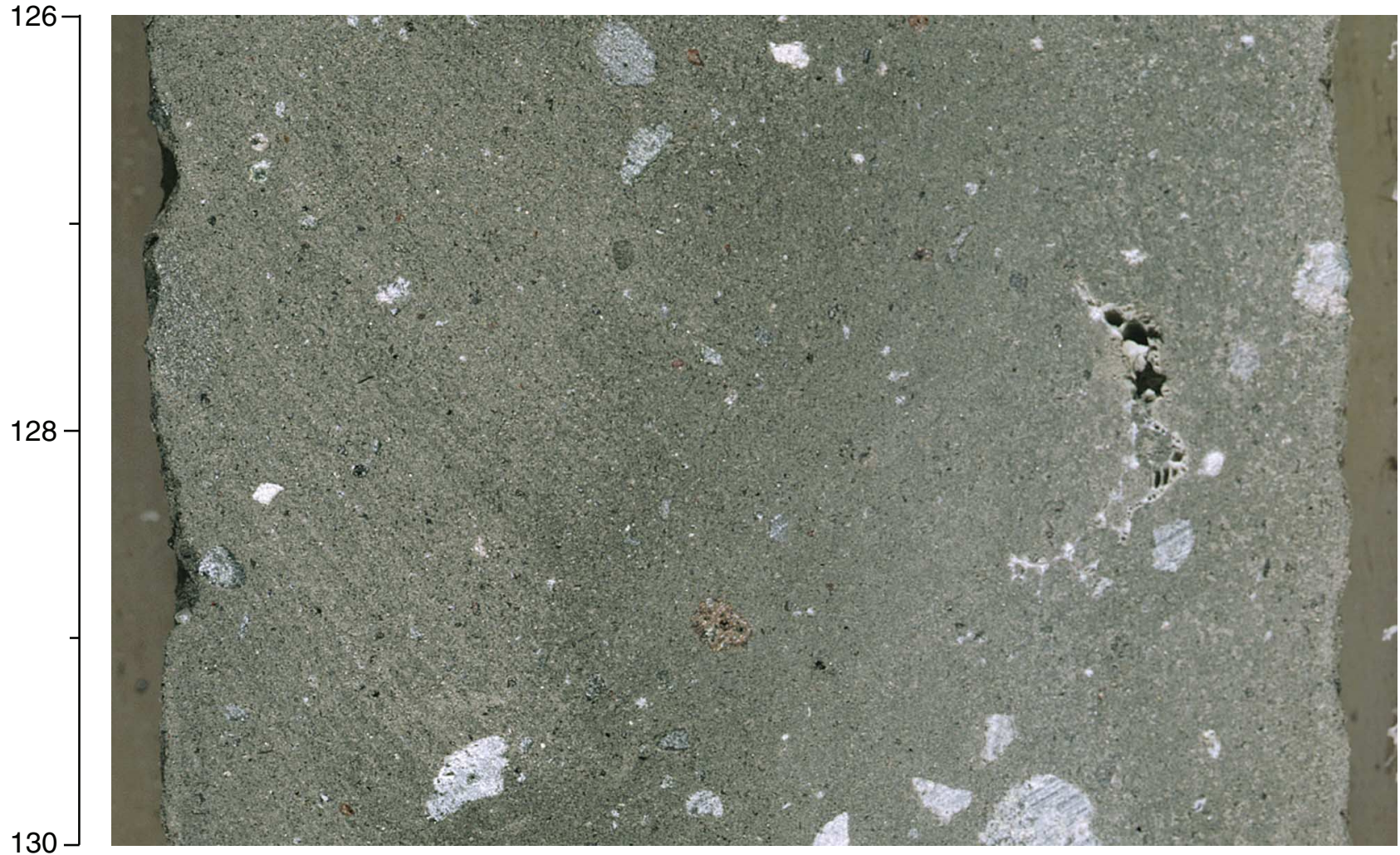


M. LAVELLE ET AL.

DATA Report: Sr ISOTOPE DATING OF BARNACLE Fragments

Plate P2. SEM ultrastructure images of barnacle fragments, Site 1103. 1-6. Figure numbers refer to the reference numbers in Table T1, p. 6.

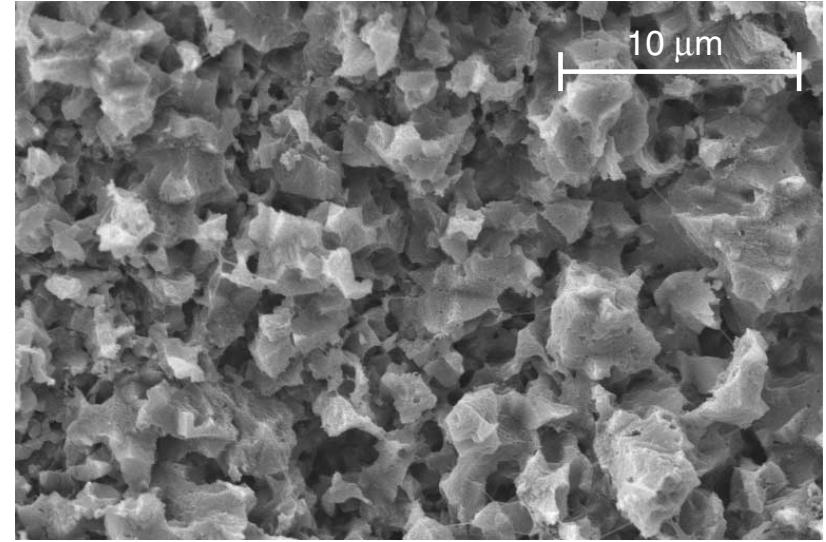

1

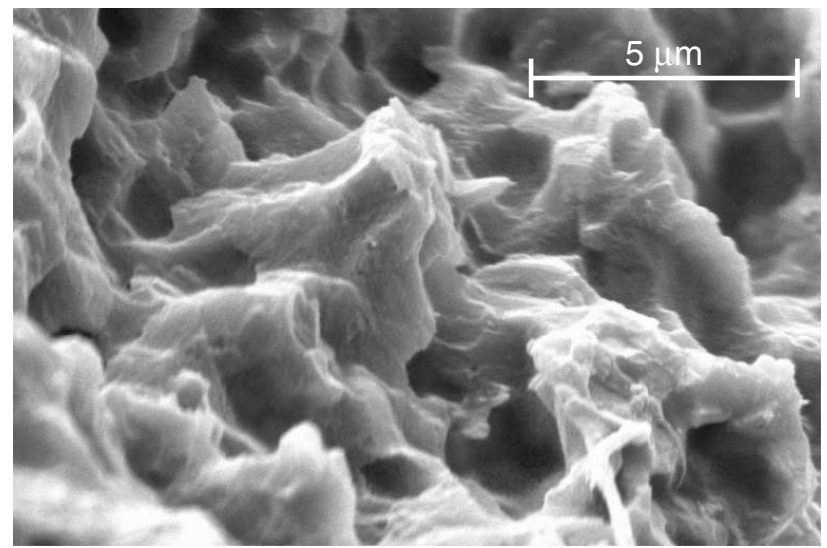

3

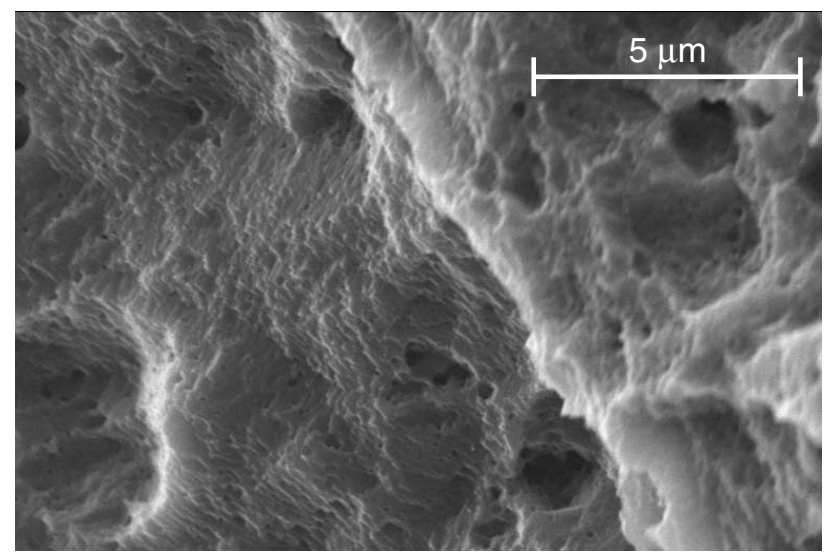

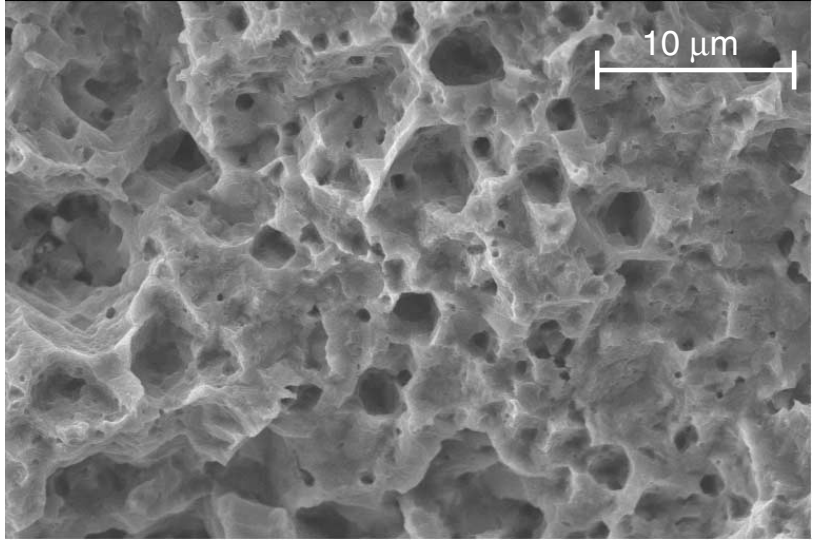

2

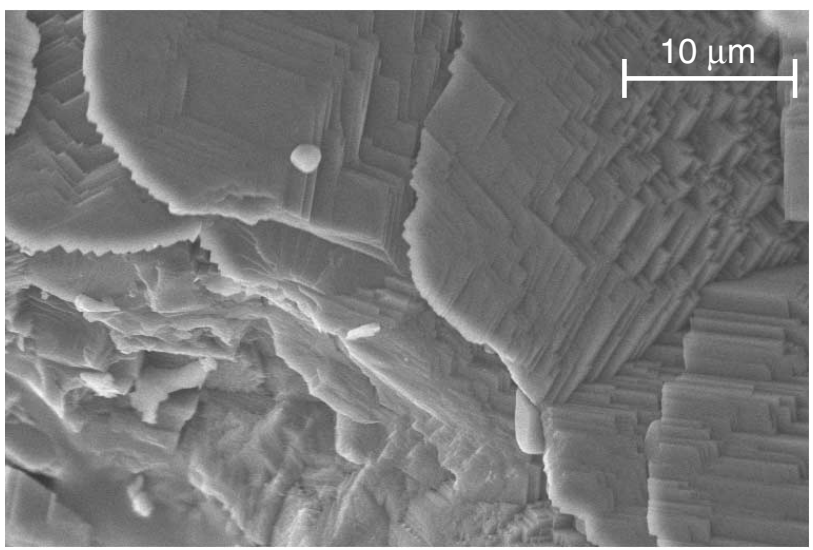

4

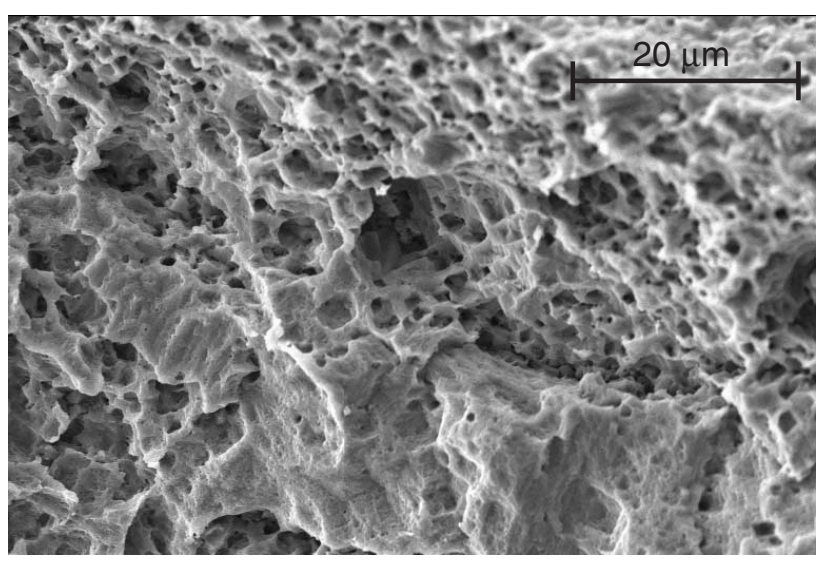

6 